\title{
The Experience and Enlightenment of the Reform and Development of Higher Engineering Education in Taiwan
}

\author{
Meng Zhang \\ Electronic Information Engineering College \\ ChangChun University \\ ChangChun, Jilin, 130022, China \\ musazhang@126.com
}

\author{
Jie $\mathrm{Li} *$, Haixin Sun \\ Electronic Information Engineering College \\ ChangChun University \\ ChangChun, Jilin, 130022, China \\ 910436792@qq.com, 4046787@qq.com
}

\begin{abstract}
The manufacturing and engineering technologies in Taiwan have certain strengths in Asia and the world. This is inseparable from the long-term emphasis on engineering and technology education in higher education. The quality of higher education and the internationalization of higher education are still continuing. In adapting to economic development, it has gradually formed a focus on economic development, built a complete technical vocational education system and engineering education system, and has certain characteristics in general education, school-enterprise cooperation, engineering education professional certification, etc. It has certain enlightening effect on the reform of higher engineering education in the mainland.
\end{abstract}

Keywords-Taiwan; engineering education; professional certification; education reform

\section{INTRODUCTION}

In June 2014, China joined the "Washington Accord", which marked the beginning of the internationally equivalent engineering education professional certification in China. Engineering education professional certification follows three basic concepts: Results-oriented, student-centered, and continuous improvement. These concepts are essential for guiding and promoting professional construction and teaching reform, guaranteeing and improving the quality of engineering education personnel training. Results-oriented education has become the mainstream concept of education reform in the United States, Britain, Canada and other countries, and has been fully adopted by engineering education professional certification[1]. The progress of this work in mainland China is still very slow, and Taiwan's positive progress in the certification of higher engineering education in recent years should arouse our attention, giving us the following enlightenment:

\section{ADHERE TO THE SOCIAL DEMAND ORIENTATION AND IMPROVE THE ADAPTABILITY OF ENGINEERING EDUCATION AND SOCIAL AND ECONOMIC DEVELOPMENT}

Throughout the development process of higher engineering education reform in Taiwan, it can be seen that higher engineering education is closely related to economic and social industries, and the development of engineering education. The

Foundation item: Jilin province education science "13th five-year plan" project(GH180091). Jilin province higher education project(SJXGK17) successful transformation of higher education has been closely related to economic and social transformation. Therefore, in the process of reform and development, we must always place engineering education in the system of social development, take social needs as the guide, actively serve economic and social development, and establish a benign interactive relationship with the social system through openness and cooperation. Gain the vitality and driving force for sustainable development. For example, the National Kaohsiung First University of Science and Technology has integrated the "Three Innovations" (creative, innovative, entrepreneurial) education into engineering education, and has accumulated a wealth of implementation experience talents, laying the foundation for the school to build an entrepreneurial university.

\section{COMPLETE APPLICATION-ORIENTED Higher} EDUCATION SYSTEM TO BUILD A SMOOTH CHANNEL FOR TALENT DEVELOPMENT

Taiwan's engineering and technical vocational education has made outstanding contributions to regional economic development, and is a model for vocational education in the world. Many colleges and universities in mainland China are not clear enough in the goal of running a school education and the orientation of running a school. There is a convergence phenomenon, and the hierarchical structure is not perfect. There is not enough connection between academic qualifications and academic system. There are "disconnected" and "missing" of academic education and continuing education. In recent years, the popularization of higher education in the mainland and the development of social economy have put forward higher requirements for the diversified development of undergraduate higher education[2]. Drawing on the successful experience of the development of engineering technology vocational education in Taiwan, the mainland should strengthen the training objectives and training styles of higherlevel engineering education at all levels, and open up the upward channel from secondary vocational, higher vocational, undergraduate to postgraduate, and build for the growth of engineering talents. A smooth "overpass". At the same time, actively guide a group of ordinary engineering undergraduate colleges to transform into application-oriented universities, develop applied high-level engineering education, and train first-line senior engineering technology application talents. 


\section{PAY ATTENTION TO GENERAL EDUCATION AND IMPROVE THE COMPREHENSIVE QUALITY OF ENGINEERING AND TECHNICAL PERSONNEL}

Taiwan's colleges and universities vigorously promote general education, so that science and technology students have a good humanities literacy, humanities students also have a certain degree of scientific and technological knowledge, greatly promoting the improvement of the comprehensive quality of college students. General education in mainland colleges and universities is still in its infancy, although some colleges and universities have raised general education to the position of professional education and made effective exploration, but the effect and experience are still insufficient. If college students do not develop good character, then the school's education is missing and incomplete. In the development of the reform of higher engineering education on the mainland, we should attach great importance to the importance of general education, set up general education institutions, reform curriculum and teaching methods, broaden the knowledge of college students' education, improve the comprehensive quality of students with the concept of training talents in all-person education, and make students have stronger development potential. Taiwan's Central Plains University to create a representative music garden, through independent learning, group discussion, literary appreciation, learning counseling, and learning with the help of one-in-one, to promote students to learn, diligent learning, guide students to develop and cultivate potential, cultivate a combination of character, professional, creative, world view of the new century talents[3].

\section{DEEPEN THE INTEGRATION OF PRODUCTION AND} EDUCATION AND PROMOTE THE COORDINATED DEVELOPMENT OF SCHOOL-ENTERPRISE COOPERATION

The combination of school-enterprise cooperation and engineering is a major feature of engineering education in Taiwan. Engineering education in Taiwan has close cooperation with industry and enterprises, and constantly adjusts the policy and mode of industry-school cooperation with the needs of economic and technological development and human resources. Article 38 of "university act" of Taiwan is clearly stipulated: Universities should cooperate with government agencies, institutions, non-governmental organizations and academic research institutions. In 1954, "Implementation plan of education construction cooperation", In1995; "Industry-school cooperative bonus plan"; in 2006,"Industry-school cooperation program"; this not only ensures the implementation of industry-school cooperation, but also provides a strong legal guarantee for both parties. The close cooperation between the school and the enterprise enables the students to get timely training of practical operation skills and increase the learning efficiency. The enterprise reserves the needed talents and shortens the gap between school education and enterprise demand. In the process of cooperation with the industry, the university not only forms its own development characteristics and improves its social reputation, but also directly promotes the industrial upgrading with its scientific research achievements and technology transfer [6].
The traditional engineering education training model on the mainland is relatively single, not closely related to industry and enterprises, the employment adaptability of college graduates is not high, and the economic and social development of the demand for engineering talents has a large gap. The enthusiasm of enterprises to participate in higher engineering education is not high, and the two sides lack the policy guarantee of interactive cooperation between the two sides. In recent years, the government and universities have been promoting the cooperation between universities and enterprises, scientific research departments and local governments, and achieved positive results. However, in order to maintain a long-term cooperation mechanism between universities and enterprises, national and local governments must introduce special systematic policies and concrete measures to encourage and support enterprises to participate in higher engineering education, and lay the policy and institutional basis for cooperation between schools and enterprises. Datong University in Taiwan, the introduction of small micro-enterprises into the school innovation and cultivation center for cultivation, at the same time to small micro-enterprises equipped with senior school tutors, regularly carry out a variety of salon activities to help enterprises solve technical and policy problems[4].

\section{PROMOTE PROFESSIONAL CERTIFICATION OF ENGINEERING EDUCATION AND IMPROVE THE \\ INTERNATIONALIZATION LEVEL OF HIGHER ENGINEERING} EDUCATION

Establishing a professional certification system for higher engineering education is an important means to improve the quality of engineering education and international competitiveness. The Taiwan region started early in the field of engineering education professional certification, and there are many experiences worth learning and learning. The certified major indicates that the education quality of the major has reached the required level, and the graduates have mastered the theory, technology, industry and social knowledge necessary for practical work in engineering technology. In 2003, the Institute of Engineering Education Taiwan(IEET)was established in Taiwan, which is responsible for the certification of engineering education. According to the international practice and general standards, the certification body, certification standards and certification procedures are set up, and the certification system of engineering specialty is built up in line with international standards. In June 2007, Taiwan acceded to the Washington agreement. Engineering education accreditation work in Taiwan has characteristics: one is the international popular "results oriented" into the certification standard (AC2004), thus clear graduate study requires a "clear and specific knowledge, attitude, and technology (ability) and understand the professional ethics and social responsibility, professional knowledge, perform research, writing papers, team cooperation and international vision" and so on with the "core competence"[7]; Second, the certification of engineering education is regarded as a process of "continuous improvement" of education. Third, it leads the engineering education in Taiwan to be in line with the international standards. The IEET certification means that graduates have obtained the passport to go global, and can directly apply for 
of international practice, has accumulated rich experience in

the relevant national or regional professional engineer license and professional qualification. Meanwhile, it also attracts foreign students to study in Taiwan. In 2015, 450 departments of more than 70 universities in Taiwan have passed IEET certification, which not only improves the quality of engineering education in Taiwan, but also improves the international competitiveness of engineering education.

The Sanquan Education of Lanyang Campus of Tamkang University in Taiwan (all the big three abroad, all-English teaching, full accommodation college) is a model of engineering education in Taiwan[5]. We should take the opportunity of joining the "Washington Accord" to further strengthen exchanges and cooperation with international certification organizations, and organically combine international standards, industry standards and engineering talent training objectives in accordance with international practice, and continuously improve the evaluation standards of higher engineering education majors. Gradually expand the scope of certification for major professional fields of engineering, introduce advanced concepts and quality assurance culture, guide the construction of engineering education, promote the reform and development of engineering education, further improve the internationalization level of higher engineering education in China, and continuously improve the quality of personnel training in higher engineering education.

\section{SUMMARY}

Above all, Taiwan's development of higher education continuously followed by engineering and technology education front, continuously explore and improve the system of engineering education certification practice, the gradual Taiwan engineering and technology education and the process certification, the engineering education of Taiwan is recognized by international engineering and technology education. The credibility of the certification system makes the core competence of graduates clear and enhances their confidence in employment. Make the teacher teaching and scientific research unity, scientific research to achieve the purpose of leading teaching. Thus, the teaching level and international competitiveness of the school are improved.

\section{REFERENCES}

[1] Jin Cheng. The road to internationalization of engineering education certification in Taiwan [J]. China Higher Education, 2010 (5). (In Chinese)

[2] Xu Yue, Han Mingyu. Experience and Enlightenment of Taiwan's Higher Education Innovation Transformation Program[J]. Journal of Fujian Commercial College, 2016(3). (In Chinese).

[3] Li Hanbang, Han Xiaoyan, Zhuang Ling. The Status Quo and Enlightenment of Taiwan's Higher Engineering Education Professional Certification[J].Journal of National Academy of Educational Administration,2009(6). (In Chinese).

[4] Chen Jianyuan: "Study on the Impact of Entrepreneurship Education and Entrepreneurial Resources on Student Entrepreneurship in Taiwanese Colleges and Universities”, Master's Thesis of Institute of Science and Technology Management, Fengjia University, 2007. (In Chinese).

[5] Zhang Yingyu, Chen Xingming. Development Process, Characteristics and Enlightenment of Higher Engineering Education in Taiwan [J]. Higher Education of Science, 2015(2). (In Chinese).

[6] Meng Xiangyin, Ji Xiuming. The Development History, Characteristics and Revelation of Taiwan Higher Engineering Education, Higher Education of Sciences,2015(2). (In Chinese).

[7] China engineering education association certification no games engineering education certification standards.(EAC2016) [EB/OL].101.110.118.33/WWW.ieet.org.tw/(106) Certification specifications for engineering education .(EAC2016).pdf. 